\title{
Growth Rates and Phenology of Some Southern California Grassland Species
}

\section{R.W. HUFSTADER}

\begin{abstract}
Highlight: Growth rates of southern California grassland species showed significant correlation with rainfall from November 1972 to June 1973. Maximum growth for the species ripgut grass, foxtail chess, wild oats, black mustard, and geniculate mustard occurred during winter and early spring. Plant development for these species began in late fall and ceased by mid-spring. It was hypothesized that species characterisitics and slope exposures are important factors in plant development subsequent to germination, whereas, rainfall is critical to germination and growth rates.
\end{abstract}

California grasslands were originally comprised of perennial grasses, but introduced European annuals such as Bromus sp. and Avena sp. (Munz and Keck 1959) have become an integral part of the California flora. These annual plant species exhibit yearly cycles of growth rates and phenologies which correspond closely to weather patterns (Hufstader 1976, 1974; Major 1963). For a plant that starts from seed each year, the ability to grow and develop rapidly when conditions are favorable would seem an important factor in determining its success. Knowledge of the timing of plant growth and development and the factors affecting them is important in the management of these annual grasslands. This paper examines the growth rates and phenologies of some southern California grassland species.

\section{Methods}

The harvest method was used to measure growth rates. That methodology is described in detail in Hufstader (1976). Correlation coefficients were calculated for total rainfall (Orange County Flood Control District Station No. 86 located near this site) and the total The
97225 .

The author is with VTN Environmental Sciences, P.O. Box 25186, Portland, Oregon

Manuscript received October 21, 1977. growth rates of both slopes for each sample period.

Phenology was ascertained during 11 site visits at various intervals between November 20,1972, and June 10, 1973, as well as during the six harvest dates, for an average of about 12 days between visits. Phenology was determined as a visual assessment of stage of growth. Six separate stages were recognized: germination (as evidenced by coleoptile presence), vegetative, immature flowers (buds), mature flowers, fruiting, and senescence.

\section{Results and Discussion}

The plant species found in the study area were ripgut grass (Bromus rigidus), foxtail chess (Bromus rubens), wild oats (Avena fatua), black mustard (Brassica nigra), and geniculate mustard (Brassica geniculata). Except for wild oats, each species was restricted to one slope: the north-facing slope having wild oats, ripgut grass, and geniculate mustard and the south-facing slope wild oats, foxtail chess, and black mustard. Geniculate mustard was not frequent enough for use in growth rate measurements, but was included in phenology. The growth rates of species on the south-facing slope ranged from 0.004 $\mathrm{g} / \mathrm{m}^{2} /$ day to $13.6 \mathrm{~g} / \mathrm{m}^{2} /$ day. The growth rates on the north-facing slope reached a maximum of $5.4 \mathrm{~g} / \mathrm{m}^{2} /$ day and a minimum of 0.02 $\mathrm{g} / \mathrm{m}^{2} /$ day. Growth rates for both slopes showed a significant correlation with rainfall (north-facing slope, $r=0.868, p<.05$; south-facing slope, $r=0.884, p<.05$ ).

For all species except foxtail chess, the maximum observed growth rates were during winter and early spring (Table 1). Foxtail chess did not exhibit a maximum growth rate until early spring, which may be related to its subdominant status (Hufstader 1976). The growth rates occurred earlier in the year than has been indicated in other studies of northern and central California annual grassland sites, where the plants exhibited maximum growth during mid-spring (Heady 1958; 
wild oats

Black mustard

Wild oats

Foxtail chess

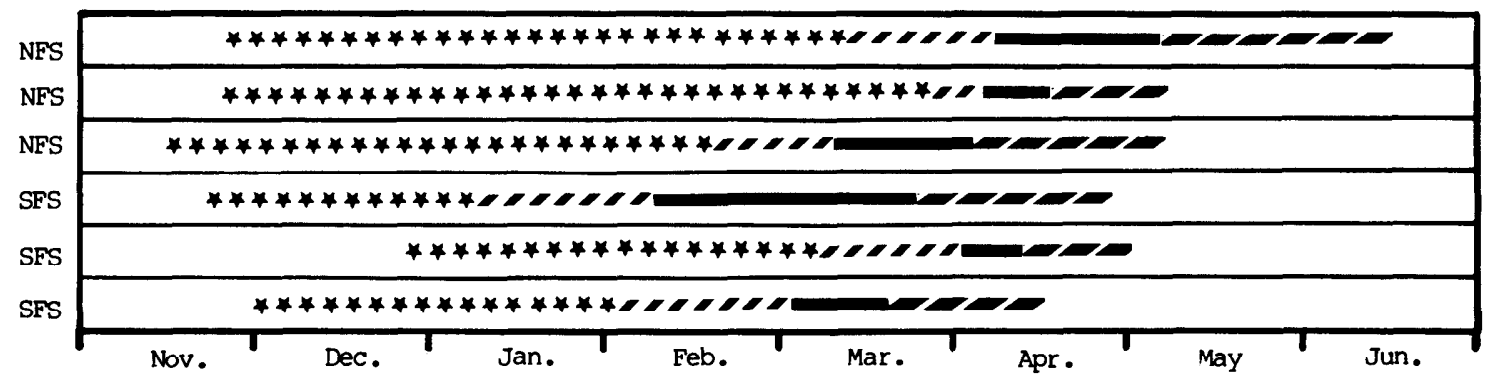

Legend

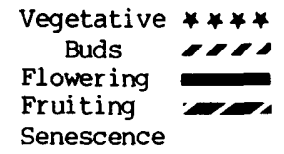

Fig. 1. Phenology of geniculate mustard, ripgut grass, wild oats, black mustard, and foxtail chess on north-(NFS) and south-(SFS) facing slopes.

Table 1. Maximum observed growth rates $\left(\mathrm{g} / \mathrm{m}^{2} /\right.$ day $)$.

\begin{tabular}{|c|c|c|}
\hline & $\begin{array}{l}\text { Growth } \\
\text { rate }\end{array}$ & $\begin{array}{l}\text { Period of } \\
\text { occurrence }\end{array}$ \\
\hline \multicolumn{3}{|l|}{ South-facing slope } \\
\hline Black mustard & 13.50 & Feb 9 - Mar 25 \\
\hline Foxtail chess & 0.04 & Mar 25-May 5 \\
\hline Wild oats & 0.11 & Feb $9-\operatorname{Mar} 25$ \\
\hline \multicolumn{3}{|l|}{ North-facing slope } \\
\hline Wild oats & 3.90 & Jan $7-$ Mar 25 \\
\hline Ripgut grass & 1.40 & Jan $7-\operatorname{Mar} 25$ \\
\hline
\end{tabular}

McNaughton 1968). However, the species found on these and other similar sites do not include black mustard or geniculate mustard (Heady 1956, 1958; McNaughton 1968; White 1966; Talbot, Biswell and Horman 1939; Biswell 1956). Species, as well as latitudinal, differences may account for much of the mid-winter and early spring growth observed on this southern site.

The first rainstorm of the season $(4.8 \mathrm{~cm})$ fell during the third week of October but no trigger germination was noted for any of the species (Fig. 1). The second storm $(7.2 \mathrm{~cm})$ fell during the second and third weeks of November. Three species, geniculate mustard, black mustard, and ripgut grass germinated during the third week of November 1972. Foxtail chess germinated during the last week of November 1972. Wild oats germinated during the second week of November on the north-facing slope, but did not germinate until late December 1972 on the south-facing aspect. Heady (1958) reported that rainstorms of between 1.3 and $2.5 \mathrm{~cm}$ were required for germination in northern sites, but an equivalent minimal rainfall requirement was not indicated for this site.

The vegetative part of the life cycles for species on the north-facing slope average about 1 month longer than on the south-facing slope. During the mid-winter period only black mustard had buds; all other species developed buds after the first of February. None of the north-facing slope species developed buds until after late-February. Species on the south-facing slope, except wild oats, began flowering in late-winter. On the north-facing slope, only wild oats was flowering by late winter. Both mustard species took just over 3 months from bud stage to senescence; all other species took less than $2 \frac{112}{2}$ months. Black mustard, wild oats, foxtail chess, and ripgut grass entered senescence between mid-April and early-May. Geniculate mustard began senescence in mid-June.

Growth rates and phenology, especially germination, appear to be largely established and determined by rainfall (Major 1963; Hufstader 1976,; Heady 1958). But plant development subsequent to germination is closely related to species characteristics and slope exposure.

Competition for light may be an important factor in differential species development, as it appears to be in the production of standing crop (Hufstader 1976). This competitive factor would be most noticeable when large, broad-leaved plants, such as black mustard, dominate the upper strata. On the south-facing slope (Fig. 1) the understory plants were substantially slower in development than black mustard.

Another factor of importance to plant development is their ability to withstand the limitations of their microclimates. Hufstader (1974) showed this south-facing slope to be more limiting to dominance expression than the north facing slope. All species on the south-facing slope began senescence earlier than species on the north-facing slope. The species on the south exposure completed their entire life cycles in shorter periods of time than species on the north exposure.

\section{Literature Cited}

Biswell, H.H. 1956. Ecology of California grasslands. J. Range Manage. 9:19-24.

Heady, H.F. 1956. Evaluation and measurement of the California annual type. J. Range Manage. 9:25-27.

Heady, H.F. 1958. Vegetational changes in the California annual type. Ecology 39:402-416.

Hufstader, R.W. 1974. Structure and function of southern California grassland on north and south slopes. MA Thesis. Cal-State Univ., Fullerton.

Hufstader, R.W. 1976. Precipitation, temperature, and the standing crop of some southern California grassland species. J. Range Manage. 29:433-435.

Major, J. 1963. A climatic index to vascular plant activity. Ecology 44:485-498.

MeNaughton, S.J. 1968. Structure and function of California grasslands. Ecology 49:962-972.

Munz, P.A., and D.D. Keck. 1959. A California Flora. Univ. Calif. Press, Berkeley. $1681 \mathrm{p}$.

Talbot, M.W., H.H. Biswell, and A.L. Hormay. 1939. Fluctuations in the annual vegetation of California. Ecology 20:394-402.

White, K.L. 1966. Old-field succession on Hastings Reservation, California Ecology 47:865-868. 